\title{
THE EGONOMIC JOURNAL
}

\author{
$M A R C H$ I994
}

The Economic Journal, 104 (March) 23i-246. (C) Royal Economic Society I994. Published by Blackwell Publishers, 108 Cowley Road, Oxford $\mathrm{OX}_{4}$ IJF. UK and 238 Main Street, Cambridge MA 02 I42, USA.

\section{FREE TRADE: OLD AND NEW GHALLENGES*}

\section{Jagdish Bhagwati}

\begin{abstract}
The paper analyses the old and new challenges to the theory and policy of Free Trade. The old challenges have sought to undermine the case for Free Trade by citing one or another type of market imperfection. Thus, the postwar period has seen two such challenges: factor market imperfections were analysed in the 1950 s to 1970 , product market imperfections in the I 980 . The new challenges are twofold. One comes from the demands for Fair Trade as a precondition for Free Trade; the other, from the concern that Free Trade, while efficient, immiserises the unskilled in the richer countries.
\end{abstract}

Having given a Harry Johnson Lecture four years ago in London, I was startled to be invited to give yet another one today. But then I recalled his unmatched productivity: his articles continued to be published even after his death, the pipelines in several journals being full of them. It is only appropriate then that he be honoured many times over. Also, in these days of preoccupation with increasing returns to scale, such a proliferation of lectures in the memory of a great economist is doubly fitting.

Since Harry Johnson was in the English tradition of taking his theory from the real world's problems and then taking it back to talk penetratingly about them, I thought it appropriate to address the earlier Johnson Lecture to the threats posed currently to the multilateral trading system by increasing resort to regionalism and to aggressive unilateralism and by the difficulties attending the completion of the Uruguay Round of multilateral trade negotiations. ${ }^{1}$ In the main, these questions relate to how we get to universal free trade for all, while not directly questioning whether free trade is good for oneself.

Today, however, I plan to address the latter, more basic issue: whether free trade for oneself is a desirable objective of policy in the first place. This is, in fact, an issue that has remained at centre stage of analysis for international economists ever since Adam Smith discussed the division of labour and David Ricardo, following James Mill, formulated the doctrine of comparative advantage and provided the essential theoretical case for free trade.

* The I993 Harry Johnson Lecture. I have profited from Irwin (1991a) and drawn in Section I on Bhagwati (1992). I am indebted to many conversations with John Chipman, Douglas Irwin, Paul Samuelson and Martin Wolf over the years on the topics I address in this lecture.

1 An expanded version of that lecture has subsequently been published as The World Trading System at Risk, in Bhagwati (r99 I c). 
Since this case is critically dependent on the assumption that market prices reflect social costs, the challenges to the doctrine of free trade have come over the last two centuries from theorists who focused on one or another market imperfection. The attendant market failure implies that market prices no longer equate social costs, requiring that the invisible hand, now frail and inadequate, must be assisted and hence free trade can be improved upon by intervention.

Thus, starting from the earliest theoretical arguments in the first half of the r 9 th century for infant industry protection and for a tariff to exploit monopoly power in trade, in the writings of John Stuart Mill and Robert Torrens, down to the post-war period when during the I950s to r 970 os economists of my generation analysed factor market imperfections while in the 1980 our students analysed product market imperfections, the theorists of commercial policy have continued to re-examine the essential case for free trade and to design appropriate policy intervention in light of the market failure at hand.

These 'conventional' market failure-based challenges to free trade have occasionally provided the intellectual support to protectionist forces, and the theoretical developments in the 1980 s in the analysis of product market imperfections (especially in the small-group models of strategic interaction) have certainly been exploited in a general way to encourage anti-free-trade sentiments and to support protectionist policies by policy-makers. There are now however new challenges in the I 99 os as we close this millennium, that come from two altogether different directions that have little to do with conventional market failures.

On the one hand, fear has grown in the developed countries, and certainly in the United States, that free trade with the developing countries will relentlessly drive down the real wages of unskilled labour. Crippled by history, Marx is striking again: immiseration of the proletariat is widely feared. With the redistributive state everywhere at bay, the market-determined wage outcomes have also become more important than ever. It then follows that, while free trade is Pareto-better in the potential-compensation sense, its adverse impact on income distribution in the absence of actual compensation makes it an unattractive policy. In the United States, where the stagnation in the real wages of the unskilled is often attributed to free trade, the unions are thus strongly opposed to embracing free trade with Mexico under the North American Free Trade Agreement (NAFTA) for much the same reason and the Clinton Administration's early hesitation about NAFTA surely reflects these fears.

At the same time, there has been an unprecedented increase in demands for 'level playing fields' as preconditions for free trade. The presumption increasingly is that unless a large and growing number of domestic policies such as environmental regulations and labour standards are harmonised by industry across countries, competition under free trade will be 'unfair'. Since few such demands can be conceded, while nearly all are based on fallacious reasoning, the implication is that free trade, perceived then to be with 'unfairly' trading rivals, will be under threat. Indeed, so it is: one of the major obstacles to closing 
the NAFTA and the Uruguay Round negotiations, for instance, has been precisely the pressure brought on the Clinton administration to accommodate the environmental lobbies on these matters.

Before I turn to these new challenges in greater depth, considering both their policy origins and their theoretical implications, permit me to put the conventional market-failure-based challenges into historical perspective so that the important developments in the scientific I980s, which are still cited by many policy-making politicians and bureaucrats as legitimation for protectionist moves in the I99os, are better assessed.

\section{THE GONVENTIONAL GHALLENGES}

The theoretical arguments for infant industry protection and a tariff to exploit monopoly power in trade remained the only serious intellectual challenges to free trade during the igth century and the early 20 th century. ${ }^{2}$

(I) The first, and in policy terms the most influential, new argument against free trade thereafter came with the onset of the Great Depression. In the lecture on Free Trade and Modern Economics in 195 I to the Manchester Statistical Society, John Hicks (1959, p. 48) recounted how the unemployment of these years had seriously undermined the belief in the doctrine of free trade:

The main thing which caused so much liberal opinion in England to lose its faith in Free trade was the helplessness of the older liberalism in the face of massive unemployment, and the possibility of using import restriction as an element in an active programme fighting unemployment. One is, of course, obliged to associate this line of thought with the name of Keynes. It was this, almost alone, which led Keynes to abandon his early belief in Free Trade.

Keynes's apostasy on free trade had been suggested in $A$ Treatise on Money ( 1930 ) and in his evidence before the MacMillan Committee in February I930 where he offered the view that tariffs, while unwise as a long-term policy, could immediately alleviate the slump. ${ }^{3}$ This viewpoint however became more pronounced in Keynes's thinking and writings through I93I, resulting in a celebrated controversy with Lionel Robbins and the Beveridge (1932)-led riposte by Robbins, Hicks et al. to Keynes in Tariffs: The Case Examined.

Interestingly, Keynes seems to have anticipated the later objection that the superior intervention to achieve full employment was domestic reflation rather than expenditure-switching protection: ${ }^{4}$

If nations can learn to provide themselves with full employment by their domestic policy... there would no longer be a pressing motive why one

\footnotetext{
2 The key historical references to these arguments are Mill $(1848)$ and Torrens $(1844)$.

3 I am indebted to Barry Eichengreen ( 1984 ), Bernard Wolf and Nicholas Smook (1988) and Douglas Irwin ( $1991 b$ ), who offer a richly textured analysis of Keynes's views on free trade.

4 Cited in Irwin (1991 $b$ ). Joan Robinson (1937) and Nicholas Kaldor (1950-51) analysed further the argument that expenditure-switching policies to deflect expenditure onto oneself were 'beggar-thyneighbour' policics.
}

(C) Royal Economic Society 1994 
country need force its wares on another or repulse the offerings of its neighbours.

Later theoretical analysis would then show how, under fixed exchange rates, the reflation would cause external imbalance and therefore the two policies, reflation and devaluation, would be generally necessary to attain the two targets of external and internal balance. Tariffs would then appear to be inferior to the optimal combination of devaluation and reflation as the policy solution to unemployment.

But these insights came later. During the r 930 , Keynes's renunciation of the doctrine of free trade remained a potent source of disbelief in the doctrine. Combined with the massive unemployment unleashed by the Great Depression and the lingering aftermath of its distress, this apostasy turned the I 930 os into the most deadly episode among the challenges to the doctrine of free trade.

(2) The rgzos also witnessed the emergence of a threat to free trade from an altogether different direction. It came, not from economic circumstance driving revisionism but entirely from autonomous theoretical progress: and that too in a curiously tangential way.

As the I 920 s ended, Edward Chamberlin (I 929) and Joan Robinson (I 93 I) independently came up with important theoretical analysis of imperfect competition, opening up to systematic exploration the middle ground between perfect competition and pure monopoly. ${ }^{5}$ The result was to undermine seriously the notion that market prices reflected social costs, calling into question more widely the virtue of laissez-faire, and, more narrowly with it, the merit of free trade as well.

The economists of the Chicago School correctly saw this as a threat that would legitimate interventionism. Therefore, they proceeded to counter the threat by taking to econometrics to demonstrate that, although markets seemed imperfect to the naked eye, in reality there was 'as if' or 'working' competition and that the imperfections were not of enough consequence to require policy intervention. Today, we talk not of 'as if' competition but of 'contestable markets': but, by and large, the key thought is the same.

Despite Chicago's riposte, however, the scepticism about prices not reflecting social costs due to imperfect competition remained a potent source of erosion in the belief that free trade was a desirable policy. In his 195I Lecture, analysing the different reasons why the doctrine of free trade had lost 'much of its strength' and 'been called into question', 6 John Hicks (1959, p. 46) captured this reality well:

5 There are differences between the two pioneers. In particular, Chamberlin's analysis was deeper on product differentiation whereas Mrs Robinson's analysis of monopsony and price discrimination would prove seminal. Chamberlin insisted on differentiating his analysis of 'monopolistic' from Mrs Robinson's analysis of 'imperfect' competition. Among those innocent of the resulting acrimony was H. D. Henderson (the Drummond Professor of Political Economy at Oxford at the time). Presiding over Chamberlin's lecture at All Souls College, Henderson introduced him, with unintended double entendre, as the 'father of the theory of imperfect competition'.

6 Hicks writes: 'Free Trade is no longer accepted by economists, even as an ideal, in the way it used to be. Economists have not lost authority, but the preponderance of economic opinion is no longer so certainly as it was on the Free Trade side' (1959, pp. 41-2).

(C) Royal Economic Society I 994 
the Monopoly-Competition argument... is of much less practical importance than the others, but it deserves at least a passing mention, because of the undoubted influence which it undoubtedly exercises - in a negative sort of way-upon the minds of economics students.... If apparent costs only equal true costs under conditions of perfect competition, and competition hardly ever is perfect, the bottom seems to drop out of the Free Trade argument. This is in fact a fair description of the state of mind which quite a number of economics students seem to have reached.

But the damage that the theory of imperfect competition did to the policy of free trade cannot be argued, as Hicks also suggests, to have been serious. There were two reasons. First, there was nothing in economic circumstance that led to the demand for protection, citing this kind of theory: the attack on free trade was of the nihilistic variety, hard to tap by specific interest groups. Besides, free trade was already imperilled far more seriously by Keynes's desertion, by the economic circumstance of massive unemployment, and by the new macroeconomic ideas that I discussed. When economists returned to imperfect competition in the 1980 s, the threat would become serious: economic circumstance would have changed, with more compelling craving for protection, and the idiom and substance of the new work on imperfect competition would be more readily accessible for exploitation and capture by the protectionist interests.

(3) Let me then turn immediately to the post-war period. The I950s to I 970 os were the decades of increasingly freer trade in the developed countries. Successive GATT Rounds of negotiations brought tariffs down to low levels. Trade expansion and income growth interacted virtuously to make these two decades the Golden Age that the later, more troubled years in the 1970s would contrast unhappily with. In this respect, this was again the heyday of free trade.

But the increasing trade liberalisation of the developed countries contrasted with the turn to import substitution and protectionist policies in much of the underdeveloped world. The newly independent developing countries were determined to use the 'infant industry' argument freely to support nascent industries. Equally, they considered these industries to be necessary features of a modern economy and society, implying what international economists in the 1960 s would call a 'non-economic' preference. Besides, it was widely believed that the developing countries were characterised by a number of market imperfections, the principal ones being in factor markets: distorting intersectoral wage differentials, sticky wages such that the market wage exceeded the shadow wage, sector-specific minimum wages and monopsony. All these implied market failure which would seem to require protection.

Interestingly, therefore, since trade theory often responds to reality, the major developments in the theory of commercial policy during this period came from, not the developed-country liberalisation (though the growth of the European Common Market did stimulate the new theory of customs and 
preferential trade liberalisation), ${ }^{7}$ but rather from the developing-country concerns and policies of protection.

Thus, the theory of optimal policy intervention in the presence of noneconomic objectives was fuelled by these concerns: its major contours were established in contributions by Corden (1957), Johnson ( $1965 a$ ), Bhagwati and Srinivasan (1969) and many others. ${ }^{8}$ But, much more so, there was an explosion of theoretical developments concerning the optimal, and second-best, policies to remedy the distorting effects of several different factor market imperfections.

However, these developments led to a most important twist in favour of free trade. Instead of underlining the need for protection to fix these market failures, these analyses led to the conclusion that the best way to address domestic distortions (such as most factor market imperfections) was through domestic policy interventions, and that in these cases protection was at best a second-best measure.

The net effect of this central insight was to narrow, not widen, the case for protection since until then it was commonly believed that protection was the appropriate way to handle all kinds of market failure. Now, protection was seen to be the first-best policy only when the distortion was foreign, not domestic. ${ }^{9}$

This insight applied equally to the important question of non-economic objectives. Symmetrically, the trade theorists showed that only when the noneconomic objective was in the foreign sector (e.g. one wanted to reduce imports in the pursuit of 'self-sufficiency'), the optimal intervention would be in the shape of protection; in other cases, it required domestic policy intervention.'

Thus, the I970s to I 980 s were characterised by contrasting phenomena:

- a substantial threat to free trade from the demands for protection from the many developing countries which, in fact, embraced extensive protection as part of their developmental strategy of import substitution; and a reduced threat to free trade from the developed countries which pursued trade liberalisation instead; and

- a substantial concern with market failure (through factor markets) and non-economic objectives, both stemming from developing-country concerns, which implied increased legitimacy for intervention and presumably therefore for trade protection; and a strengthening of the theoretical case for free trade because theoretical analysis, stimulated by these questions, showed that the appropriate intervention required was mostly in domestic markets, not in the form of trade protection.

\footnotetext{
'Starting with Viner (1950), who pioneered the distinction between trade diversion and trade creation, there were important contributions by Lipsey and Lancaster (I956-57), Lipsey (r957), Meade (r955), Johnson $\left(195^{8} a, b\right)$, and many others.

8 The influence of developing-country concerns is most evident in many other contributions to this literature, especially by Johnson $\left(\mathrm{I}_{965} b\right)$, Bhagwati (1968), and Cooper and Massell ( $\left.\operatorname{Ig}_{5} a, b\right)$.

* I might add that this was fully understood only by sophisticated economists. In the late 1970 , when the United States auto industry was looking for protection, my phone at MIT rang. A senior executive at one of the Big Three Detroit firms wanted to get me to write a paper for them, arguing for protectionist relief to the auto industry. He claimed that he had heard that $I$ had developed arguments for protection in the scientific literature. Evidently, his economist informant was confusing my many analyses of market imperfections with protectionist conclusions, if not sympathies.
} 
(4) The I980s shared with the I950s-r 970 os the distinction of having the theory of free trade extended in the realm of imperfect competition. But whereas the earlier period was concerned with factor market imperfections, the latter period was concerned with product market imperfections.

In turn, this reflected a shift from preoccupation with protectionism in the developing countries to preoccupation with protectionism in the developed countries. In fact, by the end of the r 970 , the combination of economic writings and far-ranging research into the costs of import substitution and the benefits of export promotion, conditionality imposed by the World Bank on the basis of these ideas and findings, and the example provided by the successful export-promoting nations of the Far East, had led to growing trade liberalisation among the developing countries.

By contrast, the developed countries had lapsed into resorting to non-tariff barriers (NTBs) in lieu of the reduced tariffs 'bound' at the GATT. In fact, the rise of NTBs, in the shape of Voluntary Export Restraints and 'administered protection' in the shape of the unfair use of fair trade mechanisms such as antidumping (AD) actions and (subsidy-) countervailing duties (CVD), got quite out of hand in both the EC and the United States, from the early I 980 .

The growth of protectionist outcomes reflected increases in both the 'demand for', and the 'supply of', protection. The demand for protection had escalated to unmanageable levels owing to the Volcker-led recession. In addition, the United States suffered from serious dollar overvaluation during the first Reagan administration. The United States was also succumbing to a return of the 'diminished giant syndrome' (Bhagwati and Irwin, 1987).

The intense competition among the firms of the developed countries, and the desire to protect against inroads by foreign rivals, then provided the context within which the theoretical developments, analysing the interventionist implications of the large-group model of imperfect competition, and more pointedly of the small-group oligopolistic models, were set. They caught the protectionist fancy, met the protectionist needs, and therefore immediately got into the centre stage of public policy debate.

From the protectionist viewpoint, therefore, the imperfect-competition models of the r 950 os to r 970 os were popular in the developing countries as legitimating (to the uncritical eye) their protectionism. The imperfectcompetition models of the Ig8os were equally popular in the developed countries as legitimating (to the uncritical eye) their protectionism.

As for policy, the theorists of the imperfect-competition-in-product-markets themselves have returned to the fold of free trade in one of two ways:

(i) Either, they have followed the 'Chicago school' approach of saying that the market imperfections do not amount to a hill of beans and should therefore be ignored by policy-makers. This is the view embraced, in varying degrees, by economists such as Gene Grossman ( 1986 ) who argue that the rent-shifting towards oneself by using trade policy in oligopolistic industries, scientifically shown to be a good policy intervention, requires that there be significant rents to shift; but that arguably there are few such rents in reality.

(ii) Or else, they have followed the more conservative 'Public choice school' 
approach which essentially argues that the visible hand will strangulate: intervention will produce worse outcomes than the imperfect markets that we seek to fix. This can happen if you have a predatory view of government, which should not be surprising. But it comes from the public-choice-theoretic view that special-interest lobbying will distort the outcome. Paul Krugman ( 1987 ) has taken this view.

I should add however that the theoretical developments in the I 980 s were not one-sided. The case for free trade was strengthened indirectly by the new interest in political-economy-theoretic modelling that has by now become a compelling trend in economic theorising more generally. ${ }^{10}$ In particular, the notion that the cost of protection was low and therefore unworthy of policy attention simply because the deadweight losses measured a la Harry Johnson et al. were a small fraction of the national income was seen as naive when the induced rent-seeking (Krueger, I974) or revenue-seeking (Bhagwati and Srinivasan, 1980) was taken into account. The general theory of DUP (directly unproductive profit-seeking) activities (Bhagwati, 1982) considers alternative ways in which resource-using but zero-output-producing (and income-earning) activities can result from lobbying for policy change to redistribute income towards oneself (as with tariffs) or through lobbying to share in the rents or revenues from existing policies (as when lobbies compete for rent-fetching import quotas already in place). Such DUP activities could add significantly to the deadweight cost of protection. ${ }^{11}$

While therefore the 1980 s began by marrying the rising protectionist demand in the developed countries to the theoretical developments in the theory of imperfect competition in product markets, and protectionism did break out, making the period one of high threat to free trade, it ended with the proponents of the theory backing off into free trade and with the new developments in the political-economy theory of DUP and rent-seeking activities strengthening the case against protection.

\section{THE NEW GHALLENGES}

But new challenges have arisen, as I noted at the outset, proving the adage that a free trader's life will not suffer from the ennui that follows success. Demands for fair trade and harmonisation of domestic policies and institutions in trading nations as preconditions for free trade have multiplied. Equally there is widespread concern that trade liberalisation with the poor countries will impoverish the workers of the rich countries: a fear articulated eloquently by Ross Perot and Pat Choate (1993) in their denunciation of the North American Free Trade Agreement with Mexico as 'a drastic and unfair scheme' that 'will pit American and Mexican workers in a race to the bottom'.

${ }^{10}$ See the detailed argument concerning this in my Harms Prize Lecture, Bhagwati (1988).

${ }^{11}$ Cf. Varian ( 1989 ) for measurement problems and Hillman and Riley (1989) on the analysis as to whether a dollar worth of rents would lead to a dollar worth of resource loss due to rent-seeking. A voluminous literature on the latter question is now available.

(C) Royal Economic Society 1994 


\section{Fair Trade as Precondition for Free Trade}

The demands for partial or total harmonisation of domestic policies, such as environmental and labour standards, and domestic institutions, such as the retail distribution systems and technology policies, have grown recently for a variety of reasons, even though a trade economist would normally consider diversity among trading nations to be good, rather than bad, for mutuallygainful trade. ${ }^{12}$

One reason, perhaps the most potent, is that protectionist demands are more likely to meet with approval if, instead of saying that you need help because you cannot compete, you claim that the foreigner is gaining because of his resort to unfair trade. ${ }^{13}$ The enormous use of even conventional fair-trade mechanisms, such as the levying of anti-dumping and countervailing duties (designed to offset foreign subsidies) in the r 980 is to be explained, not in terms of a genuine rise in the phenomena of predatory dumping and foreign subsidisation, but as Stigler-type capture of these mechanisms for protectionist purposes. Ironically, these fair-trade institutions have been used unfairly to get protection rather than to maintain free trade.

In my view, however, a major contributory factor has been the globalisation of the world economy and the fact that today, with the shares of trade to GNP having risen virtually everywhere in the last two decades, a great number of activities are now subject to international competition. Then again, among the OECD countries (as Baumol et al. (1989) have documented), there has been considerable convergence of technical knowhow, partly brought about by the global activities of multinationals, so that more industries than ever before are 'footloose': the number of industries that are 'shiftable' due to someone else gaining a small new advantage seems to have swelled.

The result is kaleidoscopic comparative advantage, a kind of knife edge, where one day I have comparative advantage in $X$ and you in $Y$, and tomorrow it may be the other way around, and then back again: a sort of musical chairs. ${ }^{14}$ Then two consequences follow, each relevant to one of the two new challenges to free trade that I have distinguished.

First, in this threatening new world, producers will become very sensitive to the possibility that their foreign competitors are deriving their lethal competitive edge because of some 'unfair' advantage that they 'should not' have. Each will be looking over the others' shoulders to see if some domestic institution or. policy is fetching such unfair advantage to them. The fact that they do not have the same environmental regulations, that they do not have to meet the same safety standards, are among the most common complaints today

\footnotetext{
12 Of course, harmonising 'standards' is not the same as harmonising tastes or endowments. The latter will reduce gains from trade by reducing the diversity that produces trade. But getting another country to, say, adopt a minimum wage similar to one's own may increase one's gains from trade by increasing its demand for one's exports at given terms of trade.

${ }^{13}$ Cr. Bhagwati (I991 $c$ ) for a fuller analysis of other factors contributing to the rise of unfair trade concerns.

14 Cf. Bhagwati (1991 $a$ ).
}

(C) Royal Economic Society 1994 
in the countries which have stiffer standards, these being generally the OECD countries.

As the recently-concluded NAFTA 'supplemental' agreements on these questions suggest, since President Salinas of Mexico had to agree to raising the minimum wage in Mexico, it is only a short step, if not a slippery slope, to then asking that even wages be raised in the poor countries if free trade is to be permitted with them: the infamous 'pauper-labour' argument would be resurrected.

The second consequence is that the volatility of comparative advantage will lead to greater labour turnover and hence could impede the acquisition of skills on the job, thus flattening the growth curve of earnings for labour. As argued in Bhagwati (1991 $a, b$ ) and formalised in Dehejia (1992), a rolling stone gathers no moss and a moving worker gains no skills. ${ }^{15}$ We may then have here a rather novel reason why trade may impact adversely on wages, contributing to the second new challenge to free trade that I consider below.

Returning to the question of fair trade, however, it is evident that the belief that harmonisation of domestic policies and institutions is generally essential prior to free trade is based on the erroneous notion that, without such harmonisation, trade will cease to be a mutual-gain phenomenon and will instead lead to predation. Economic analysis can readily confirm that this is a false notion, in general. Diversity of domestic policies, institutions and standards is generally compatible with gainful free trade.

Nonetheless, the popular assumption and demand today is that if your rival abroad has lower environmental and labour standards, that amounts to 'social dumping' by him in your market and therefore you should be permitted to impose countervailing import duties. This notion, gaining ground in EC and the United States, is based on two obvious fallacies: (i) the differences in standards in the same industries as between countries will reflect legitimately different priorities among nations in their objectives, as when Mexico may prefer to use its budget on prevention of pollution of a lake by chemicals from paper mills rather than to reduce $\mathrm{CO}_{2}$ emissions from lead-containing fuel whereas the United States prefers it the other way around; and (ii) the same general standards, such as taxing of $\mathrm{CO}_{2}$ emissions, will generally produce nonneutral effects on comparative advantage (whereas focus on cross-national within-same-industry comparisons of environmental and such 'burdens' focuses mistakenly on absolute advantage).

Besides, it is evident that this approach opens a Pandora's box. Once it is admitted, despite lack of economic logic, that cost differences due to differential domestic policies can be countervailed, even if it is originally in the context of 'good' causes such as environmental and labour, it becomes an invitation to protectionists to cite ever more such reasons for imposing countervailing duties:

15 An Economics Focus column in The Economist (1993) cites a forthcoming OECD study that confirms the relationship between turnover and skill acquisition hypothesised in Bhagwati (1991 $a$ ). 
a tendency already manifest in the United States in relation to the highlycompetitive trade with Japan and the NAFTA negotiations as well. ${ }^{16}$

\section{Trade and Wages $^{17}$}

The other, equally potent, challenge to free trade comes from the fear of the income-distributional effects of trade with the South. Indeed, it is curious that there has been a reversal of attitudes among the countries of the North and of the South when trade between them is appraised. During the I95os and I96os, much of the South regarded trade with the North as a threat, not as an opportunity, was afraid that without protection it could not industrialise, and turned to import substitution while the North was opening to the South (as to itself) through extensive liberalisation. Today, starting with the late I98os, there have been fearful voices in the North, dreading trade with the poor South as a recipe for descent into the wages and working conditions of these impoverished nations, whereas many in the South now see trade with the North as an opportunity, not a peril. The contrast between Mexico's and the US Congress' reaction to NAFTA is a stark example of this role reversal.

Interestingly, the major theoretical construct which, implicitly or explicitly, has provided the intellectual support, and lent the air of plausibility, to the fears in the North of immiseration of the unskilled from freer trade with the South has been the celebrated Factor Price Equalisation (FPE) theorem (and the Stolper-Samuelson (SS) theorem which shows the adverse impact of free trade on the factor of production that is scarce in the country relative to abroad in the country's trading partners, i.e. presumably unskilled labour in the North vis-à-vis unskilled labour in the South, relative to other factors of production such as capital). ${ }^{18}$

It is interesting, of course, that when Paul Samuelson (1948, I949) wrote his famous pair of articles on the FPE theorem in this JournaL, the theorem was considered at first to be implausible and hence possibly wrong, and then to be little more than a theoretical curiosum. ${ }^{19}$ At the same time, when Wassily Leontief came up with his startling finding that the United States was exporting labour-intensive exports, the search for explanations that was set off primarily focused on the reasons why the FPE theorem, building on the Heckscher-Ohlin-Samuelson model, would not hold in the real world because one or more of the sufficiency conditions (such as absence of factor-intensity reversals) were unrealistic. In short, the approach to the FPE theorem was not

\footnotetext{
16 The full range of analytical issues raised by the demands for harmonisation of domestic policies and institutions is addressed in a number of papers being written under a Ford Foundation-financed project on Fair Trade Claims and Gains from Trade, directed by me and Professor Robert Hudec of the University of Minnesota Law School.

17 The arguments in this section have been developed more fully in Bhagwati and Dehejia (1993).

18 In the symmetric $n \times n$ case, the FPE theorem implies the SS theorem (as stated above), but the SS theorem does not imply the FPE theorem. In principle, it is enough to have the SS theorem to generate the fears that, if one is importing labour-intensive goods from the poor, labour-abundant South, free trade will harm the real wage of labour.

${ }_{10}$ Paul Samuelson informs me that his 1949 article was written to explicate the results of the 1948 article and that two articles sceptical of the latter had to be destroyed in proof by this Journal.
} 
that it defined reality; rather it was that the theorem provided the researcher with the necessary clues as to why it did not.

By contrast, the tendency today is to regard FPE as an inescapable destiny: with the (unskilled) proletariat facing an inevitable immiseration or, at minimum, a heavy drag on the rise of its real wages. But it is time to remind ourselves that the original view of the FPE theorem was correct: its assumptions are indeed extraordinarily demanding. It is not therefore a compelling, or adequate, guide to real-world phenomena.

Consider, in particular, just three reasons why the presumption that real wages in the North and the South will converge as a result of free trade can be considered unrealistic. I will relate them to the SS theorem instead, assuming that the rich country is importing (unskilled) labour-intensive goods and exporting (human and physical) capital-intensive goods and that the terms of trade improve when trade is freed. In this $(2 \times 2)$ version of the theorem, which is consonant with the FPE theorem, the real wage of unskilled labour falls. ${ }^{20}$

I. Scale Economies. Scale economies can invalidate the SS theorem, causing both factors' real wages to rise. The reason is obvious: the redistributive effect which militates against the real wage of unskilled labour can be outweighed by the lifting-all-boats effect of scale economies on the marginal products and hence real wages of both factors.

The first theoretical demonstration of this phenomenon was by Arvind Panagariya ( I98I) who modelled scale economies in the old way where they were external to the firm but internal to the industry, thus retaining our ability to work with models of perfect competition.

Helpman and Krugman (I985) established the same conclusion in the context of scale economies internal to the firm, and hence under imperfect competition. Their analysis was, however, restricted to the special case where the output per firm did not rise with trade so that the added gains from trade were due to variety rather than reduced cost thanks to scale. Brown et al. (I 993) have now produced a more general and illuminating analysis allowing for both these (and other) effects.

2. Diversification. The SS theorem (as also the FPE theorem) depend on the equilibria under autarky and free trade lying in the diversification cone, i.e. trade should not lead to complete specialisation. When it does, the unique relationship between goods and factor prices breaks down: while the factor prices are unique at complete specialisation on a good, goods prices are manifestly not since raising prices for the good will be compatible with continued specialisation on the good. ${ }^{21}$

Equally, while the SS redistributive effect operates as long as trade shifts production towards a good without causing complete specialisation, once specialisation is achieved, any further rise in that good's (relative) price will

20 Thus, instead of focusing on whether there is convergence of real wages in South and North, we focus directly on the question on centre stage: will cheaper labour-intensive imports from the South under freer trade cause our real wages of the unskilled to fall? In principle, of course, it is theoretically possible for the latter to occur while FPE fails: e.g. the factors that militate against SS, detailed above, may hold in the South and not in the North.

${ }^{21}$ I am working here with the $2 \times 2$ version of the SS and FPE theorems.

(C) Royal Economic Society 1994 
clearly mean that both factors will gain from it: the lifting-all-boats effect from this improvement in the terms of trade (implied by the rise in the relative price of the specialised good where, and in terms of which, their reward is fixed at specialisation) will ensue. The net effect could be to leave both factors better off under free trade than under autarky.

But this lifting-all-boats effect will help each factor proportionately to how much it consumes of the cheaper imported goods, of course. Hence it is pertinent to observe that, as the work of William Cline (1990) on textiles shows and as casual empiricism suggests for other imported goods such as low-quality footwear, the groups at the bottom of the income distribution (which must include the unskilled) disproportionately spend their incomes on imported goods whose prices are heavily influenced by protection (such as the VERs on footwear and the MFA on textiles). Deardorff and Haveman (1992) have made the complementary observation that the invoking of administered protection has been typically for industries which are not intensive in the incidence of poverty in their workforce suggesting that protection so given is, in its direct effect, to the (relative) disadvantage of the industries that are and hence of the poor.

3. Trade and Competition. The lifting-all-boats effect can also arise if trade means more competition and discipline, causing $x$-efficiency effects which may be captured analytically as Hicks-neutral technical change. If this is done, and it is assumed that the effect operates throughout the economy, in both traded sectors, then clearly both factors get their real wages improving from this, countervailing and possibly reversing the fall in the real wage of the SSimpacted factor.

But, even if we were to assume that the production-function-improvement arises differentially more in the import-competing sectors, we can see immediately from the early work on the general-equilibrium income-elasticities of supply under technical change ${ }^{22}$ that, ceteris paribus, the effect will be to raise the real wage of the factor intensively used in these sectors: i.e. of unskilled labour in this instance.

The econometric evidence on this hypothesis is hard to find. However, Jim Levinsohn's (1993) recent work on the imports-as-competition hypothesis, while not exactly specified in the manner suggested here, and successful in testing that hypothesis with the use of Turkish industry data under nearcontrolled-experiment conditions, does suggest that my specification of the effects of trade on technical change via competition may also be borne out.

In fact, the general consensus that seems to be building now among the labour and trade economists studying the 1980s wages-of-the-unskilled experience is that trade is not a significant cause of the phenomenon and that the true culprit is technology and technical change. ${ }^{23}$

The new information technology is reinforcing Griliches' (1969) original view that skilled labour is relatively more complementary to capital: a computer can displace several unskilled workers and create a job for one skilled

22 Cf. the beautiful paper by Findlay and Grubert (1959).

${ }^{23}$ For a detailed review and analysis, see Bhagwati and Dehejia (1993). 
operator. $^{24}$ The impact of both sources of growth, capital accumulation and technical change, can then be to reduce, not increase, the real wage of the unskilled.

Marx may indeed be striking again, but not with the assistance of Samuelson. ${ }^{25}$ The task before us then is to make this amply clear before the fear of trade with the 'Asiatic ants' and the 'reserve army' of cheap labour in the poor countries gets out of hand.

\section{Columbia University}

\section{REFERENGES}

Bartel, Ann P. and Lichtenberg, Frank R. (1957). 'The comparative advantage of educated workers in implementing new technology.' Review of Economics and Statistics, vol. 69, pp. 343-59.

Baumol, William J., Blackman, Sue Anne B. and Wolff, Edward N. (1989). Productivity and American Leadership: The Long View. Cambridge, MA: MIT Press.

Berndt, Ernst R. and Morrison, Catherine (1991). 'High-tech capital, economic performance and labor composition in U.S. manufacturing industries: an exploratory analysis.' Unpublished manuscript, Cambridge, MA, MIT.

Beveridge, W. (ed.). (1932). Tariffs: The Case Examined. New York: Longmans, Green and Co.

Bhagwati, Jagdish (1968). 'Trade liberalization among LDCs, trade theory and Gatt rules.' In Value, Capital and Growth (ed. J. N. Wolfe). Edinburgh: Edinburgh University Press.

Bhagwati, Jagdish (1982). 'Directly-unproductive profit-seeking (DUP) activities.' Journal of Political Economy, vol. 9o, pp. 988-1002.

Bhagwati, Jagdish (1988). 'Is free trade passé after all?' Weltwirtschaftliches Archiv, vol. 125, pp. 17-44; reprinted as Chapter $\mathrm{I}$ in J. Bhagwati, Political Economy and International Economics (ed. Douglas Irwin). Cambridge, MA: MIT Press.

Bhagwati, Jagdish (1991 a). 'Free traders and free immigrationists: strangers or friends?' Russell Sage Foundation Working Paper no 20, New York: Russell Sage Foundation.

Bhagwati, Jagdish ( $1991 b$ ). 'Trade and income distribution.' Paper presented at the Columbia University conference on Deindustrialization, New York.

Bhagwati, Jagdish ( 199 I $c$ ). The World Trading System at Risk. Princeton: Princeton University Press.

Bhagwati, Jagdish (I992). 'Fair trade, reciprocity and harmonization: the new challenge to the theory of policy of free trade', to appear in Analytical and Negotiating Issues in the Global Trading System (ed. Alan Deardorff and Robert Stern). Michigan: Michigan University Press, I 993

Bhagwati, Jagdish and Dehejia, Vivek (I993). 'Freer trade and wages of the unskilled: is Marx striking again?' Paper presented at the Workshop on Trade and Wages at the American Enterprise Institute, Washington, DC: September ro.

Bhagwati, Jagdish and Irwin, Douglas ( 1987 ). 'The return of the reciprocitarians: US trade policy today.' The World Economy, vol. io, pp. rog-30.

Bhagwati, Jagdish and Srinivasan, T. N. (1969). 'Optimal intervention to achieve non-economic objectives.' Review of Economic Studies, vol. 36, pp. 27-38.

Bhagwati, Jagdish and Srinivasan, T. N. (1980). 'Revenue-seeking : a generalization of the theory of tariffs.' Journal of Political Economy, vol. 88, pp. 1069-87.

Bound, John and Johnson, George (1992). 'Changes in the structure of wages in the 1980's: an evaluation of alternative explanations.' American Economic Review, vol. 82, pp. $371-92$.

Brown, Drusilla K., Deardorff, Alan V. and Stern, Robert M. (r993). 'Protection and real wages: old and new trade theories and their empirical counterparts.' Paper presented at the CEPR/CESPRI conference on new trade theories, Bocconi University, Milan, 27-8 May.

Chamberlin, Edward (1929). The Theory of Monopolistic Competition. Cambridge, MA: Harvard University Press.

Cline, William R. (1990). The Future of World Trade in Textiles and Apparel. Washington, D.C.: Institute for International Economics.

\footnotetext{
24 See the evidence in Bartel and Lichtenberg (1987), Berndt and Morrison (1991) and Krueger (1993), for instance.

${ }^{25}$ For empirical studies linking technical change to wages, see in particular Bound and Johnson (I992), Davis and Haltivanger (199I) and Mincer (I99I). I have not dealt here in depth with the rolling-stonegathers-no-moss linkage between trade and wages, touched upon in this section, because no empirical exploration of it is yet available.
} 
Cooper, Charles A. and Massell, Benton F. (1965a). 'A new look at customs union theory.' Economic JourNal, vol. 75, pp. 742-7.

Cooper, Charles A. and Massell, Benton F. $(1965 b)$. 'Toward a general theory of customs unions for developing countries.' Journal of Political Economy, vol. 73, p. $4^{61-76}$.

Corden, W. M. (1957). 'Tariffs, subsidies and the terms of trade.' Economica, vol. 24.

Davis, Steven and Haltiwanger, John (1991). 'Wage dispersion between and within U.S. manufacturing plants, 1963-86.' Brookings Papers on Economic Activity, Microeconomics, pp. $115-80$.

Deardorff, Alan V. and Haveman, Jon D. ( I 991 ). 'The effects of U.S. trade laws on poverty in America.' Discussion Paper no 285, Institute of Public Policy Studies, Ann Arbor, University of Michigan.

Dehejia, Vivek H.(r992). 'Kaleidoscopic comparative advantage and the rising skill differential.' Unpublished manuscript, New York, Columbia University.

Dixit, Avinash (1992). 'Investment and hysteresis.' Journal of Economic Perspectives, vol. 6, pp. 107-32.

The Economist (1993). 'Musical Chairs.' Economics Focus column, i 7 July.

Eichengreen, Barry (1984). 'Keynes and protection.' Journal of Economic History, vol. 44, pp. $363-73$.

Findlay, Ronald and Grubert, Harry (1959). 'Factor intensities, technological progress and the terms of trade.' Oxford Economic Papers, vol. I I, pp. I I I-2 I.

Griliches, Zvi (1969). 'Capital-Skill complementarity.' Review of Economics and Statistics, vol. 5I, pp. 465-8.

Grossman, Gene (1986). 'Strategic export promotion: a critique.' In Strategic Trade Policy and the New International Economics (ed. Paul R. Krugman), Cambridge, MA: MIT Press.

Helpman, Elhanan and Krugman, Paul R. (1985). Market Structure and Foreign Trade. Cambridge, MA: MIT Press.

Hicks, John R. (1959). Essays in World Economics. Oxford: Clarendon Press.

Hillman, Arye and Riley, John (1989). 'Politically contestable rents and transfers.' Economics and Politics, vol. I, pp. 17-39.

Irwin, Douglas ( 199 I $a$ ). 'Challenges to free trade.' Journal of Economic Perspectives, vol. 5, pp. $201-8$.

Irwin, Douglas (1991 $b$ ). 'Keynes and the macroeconomics of protection.' University of Chicago Business School, mimeographed.

Johnson, Harry G. (1958a). 'The gains from free trade with Europe: an estimate' Manchester School of Economics and Social Studies, vol. 26, pp. 247-55.

Johnson, Harry G. ( $195^{8 b}$ ). 'The economic gains from free trade with Europe.' Three Banks Review, vol. 39, pp. 3-19.

Johnson, Harry G. ( $1965 a)$. 'Optimal trade intervention in the presence of domestic distortions.' In Trade, Growth and the Balance of Payments (ed. R. E. Caves, H. G. Johnson and P. B. Kenen). Amsterdam: North-Holland Publishing Co.

Johnson, Harry G. ( $1965 b$ ). 'An economic theory of protectionism, tariff bargaining, and the formation of customs unions.' Journal of Political Economy, vol. 73 , pp. $256-83$.

Kaldor, Nicholas (1950-51). 'Employment policies and the problem of international imbalance.' Review of Economic Studies, vol. 19, pp. 42-9.

Keynes, John M. (1930). A Treatise on Money. London: Macmillan.

Krueger, Alan B. (1993). 'How computers have changed the wage structure: evidence from microdata, I 984-1989.' Quarterly Joumal of Economics, vol. 108, pp. 33-60.

Krueger, Anne O. ( 1974 ). 'The political economy of the rent-seeking society.' American Economic Review, vol. 69 , pp. $29 \mathrm{I}-303$.

Krugman, Paul (1987). 'Is free trade passe?' Joumal of Economic Perspectives, vol. 1. pp. 133-44.

Levinsohn, James (1993). 'Testing the imports-as-market-discipline hypothesis.' Journal of International Economics, vol. 35, pp. 1-22.

Lipsey, Richard G. ( 1957 ). 'The theory of customs unions: trade diversion and welfare.' Economica, vol. 24, pp. 40-6.

Lipsey, Richard G. and Lancaster, Kelvin J. (1956-57). 'The general theory of second best.' Review of Economic Studies, vol. 24; pp. $1 \mathrm{I}-3^{2}$.

Meade, James E. (1955). The Theory of Customs Unions. Amsterdam: North-Holland.

Mill, John Stuart (1848). Principles of Political Economy. London: Longman, Green, and Co.

Mincer, Jacob (1991). 'Human capital, technology and the wage structure.' Mimeographed. Columbia University: New York.

Panagariya, Arvind (1880). 'Variable returns to scale in general equilibrium theory once again.' Journal of International Economics, vol. 10, pp. 499-526.

Perot, Ross and Choate, Pat (1993). Save Your Job, Save Our Country: Why NAFTA Must Be Stopped Now!. New York: Hyperion.

Robinson, Joan (1931). The Economics of Imperfect Competition. London: Macmillan.

Robinson, Joan ( I937). 'Beggar-my-neighbour remedies for unemployment.' In Essays in the Theory of Unemployment. New York: Macmillan.

Samuelson, Paul A. (1948). 'International trade and the equalisation of factor prices.' Economic Journal, vol. 58 , pp. $16_{3}-84$. 
Samuelson, Paul A. (1949). 'International factor-price equalisation once again.' Economic JournaL, vol. 59, pp. I $81-97$.

Samuelson, Paul A. (1992). 'A new revolution at century's end.' Unpublished manuscript, Cambridge, MA, MIT.

Stolper, Wolfgang and Samuelson, Paul A. (1941). 'Protection and real wages.' Review of Economic Studies, vol. 9 , pp. $5^{8-73}$.

Torrens, Robert ( 1844$)$. The Budget: On Commercial and Colonial Policy. London: Smith, Elder.

Varian, Hal (1989). 'Measuring the deadweight costs of DUP and rent seeking activities.' Economics and Politics, vol. I, pp. $8 \mathrm{I}-95$.

Viner, Jacob (1950). The Customs Union Issue. New York: Carnegie Endowment for International Peace.

Wolf, Bernard and Smook, N. (1988). 'Keynes and the question of tariffs.' In Keynes and Public Policy after Fifty Years, vol. II (ed. O. F. Hamouda and J. N. Smithin). New York: University Press. 
Copyright of Economic Journal is the property of Blackwell Publishing Limited. The copyright in an individual article may be maintained by the author in certain cases. Content may not be copied or emailed to multiple sites or posted to a listserv without the copyright holder's express written permission. However, users may print, download, or email articles for individual use. 